\title{
Asuhan Keperawatan Jiwa Pada Ny.H Dengan Risiko Perilaku Kekerasan Di Desa Juli Seutuy Bireuen
}

\author{
DWI UTARI \\ utari1007@gmail.com
}

\section{BAB 1}

\section{PENDAHULUAN}

\subsection{Latar Belakang}

Skizofrenia merupakan sekelompok reaksi psikotik yang memengaruhi berbagai area fungsi individu termasuk berpikir, berkomunikasi, menerima, menginterpretasikan realitas, merasakan dan menunjukkan emosi (Pardede \& Hulu, 2020). Skizofrenia adalah penyakit mental yang kompleks dan sangat diturunkan, yang sangat mempengaruhi kualitas hidup. Kira-kira $1 \%$ dari populasi global menderita skizofrenia, dan angka kejadiannya serupa di berbagai negara, kelompok budaya dan jenis kelamin (Fei et al, 2021). Menurut (WHO, 2019) Skizofrenia merupakan gangguan mental berat dan kronis yang menyerang 20 juta orang diseluruh dunia. Di Indonesia berdasarkan hasil Riskesdes (2018) didapatkan estimasi prevalensi orang yang pernah menderita skizofrenia di Indonesia sebesar 1,8 per 1000 penduduk (Pardede, 2020).

Prevalensi skizofrenia/psikosis di Indonesia sebanyak 6,7 per 1000 rumah tangga. Artinya, dari 1.000 rumah tangga terdapat 6,7 rumah tangga yang mempunyai anggota rumah tangga (ART) pengidap skizofrenia/psikosis. Penyebaran prevalensi tertinggi terdapat di Bali dan DI Yogyakarta dengan masing-masing 11,1 dan 10,4 per 1.000 rumah tangga yang mempunyai ART mengidap skizofrenia/psikosis. Prevalensi (permil) rumah tangga dengan ART gangguan jiwa skizofrenia/psikosis menurut provinsi, Sumatera Utara 6,3\%, Sumatera Barat 9,1\%, Riau 6,1\%, Jambi 6,6\%, Sumatera Selatan 8,0\%, Bengkulu 5,3\%, Lampung 6,0\%, Bangka Belitung 6,7\%, Kepulauan Riau 2,8\%, DKI Jakarta 6,6\%, Jawa Barat 5,0\%, Jawa Tengah 8,7\%, Jawa Timur 6,4\%, Banten 5,7\%, Nusa Tenggara Barat 9,6\%, Nusa Tenggara 
Timur 3,6\%, Kalimantan Barat 7,9\%, Kalimantan Tengah 4,4\%, Kalimantan Selatan 5,1\%, Kalimantan Timur 5,1\%, Kalimantan Utara 7,4\%, Sulawesi Tengah 4,4\%, Sulawesi Selatan 8,8\%, Sulawesi Tenggara 5,6\%, Gorontalo 6,6\%, Sulawesi Barat 7,7\%, Maluku 3,9\%, Maluku Utara 4,8\%, Papua Barat 6,8\% dan Papua 4,5\%. Sedangkan untuk provinsi Aceh 8,7\% dengan ART yang mengidap skizofrenia/psikosis ( Riskesdas, 2018)

Skizofrenia menimbulkan distorsi pikiran, distorsi persepsi, emosi, dan tingkah laku sehingga pasien dengan skizofrenia memiliki resiko lebih tinggi berperilaku agresif dimana perubahan perilaku secara dramatis terjadi dalam beberapa hari atau minggu. Pasien skizofrenia sering dikaitkan dengan perilaku yang dapat membahayakan diri sendiri maupun orang lain ataupun berisiko juga dengan lingkungan sekitarnya, baik secara fisik, emosional, seksual, dan verbal yang disebut sebagai risiko perilaku kekerasan ( Pardede, Simanjuntak \& Laia, 2020 )

Risiko perilaku kekerasan merupakan salah satu respon marah diekspresikan dengan melakukan ancaman, mencederai diri sendiri maupun orang lain dan dapat merusak lingkungan sekitar. Tanda dan gejala risiko perilaku kekerasan dapat terjadi perubahan pada fungsi kognitif, afektif, fisiologis, perilaku dan sosial. Pada aspek fisik tekanan darah meningkat, denyut nadi dan pernapasan meningkat, mudah tersinggung, marah, amuk serta dapat mencederai diri sendiri maupun orang lain (Pardede, Siregar \& Hulu, 2020)

Perilaku kekerasan terjadi karena adanya hasil akumulasi frustasi yang berulang dan dikarenakan keinginan individu yang tidak tercapai atau bahkan gagal, sehingga individu berperilaku agresif (Suerni \& Livana, 2019). Faktor risiko yang dapat ditimbulkan oleh pasien yang mengalami perilaku kekerasan adalah dapat membahayakan diri sendiri dan orang lain, untuk memperkecil dampak yang ditimbulkan, dibutuhkan penanganan risiko perilaku kekerasan yang tepat. Penanganan pasien dengan resiko perilaku kekerasan dapat dilakukan dengan farmakologi dan strategi pelaksanaan pada pasien resiko perilaku kekerasan, 
tindakan keperawatan pada pasien resiko perilaku kekerasan difokuskan pada aspek positif, intelektual, emosional, dan sosio spiritual. Salah satunya adalah dengan menerapkan asuhan keperawatan jiwa. (Wardhani, Prabowo \& Brilianti, 2020).

Survei awal pada pembuatan askep pada skizofrenia ini dilakukan di Desa Juli Seutuy yang ditemukan pasien resiko perilaku kekerasan atas nama inisial Ny.H yang pernah di rawat di RSJ. Penyebabnya Ny.H dijadikan subjek dikarenakan Ny.H belum sepenuhnya bisa mengatasi emosinya. Maka tujuan asuhan keperawatan yang akan di lakukan ialah untuk mengajarkan standar pelaksanaan resiko perilaku kekerasan/perilaku kekerasan pada Ny.H

\subsection{Rumusan Masalah}

Berdasarkan latar belakang masalah tersebut maka dapat dirumuskan masalah saebagai berikut : Bagaimana Memberikan Asuhan Keperawatan Jiwa Pada Ny.H dengan Risiko Perilaku Kekerasan di Desa Juli Seutuy

\subsection{Tujuan Penulisan}

Adapun tujuannya sebagai berikut :

\subsubsection{Tujuan Umum}

Penulis mampu memberikan asuhan keperawatan jiwa pada Ny.H dengan Risiko Perilaku Kekerasan di Desa Juli Seutuy

\subsubsection{Tujuan Khusus}

a. Mahasiswa mampu mengetahui defenisi, tanda \& gejala,faktor penyebab, mekanisme koping, penatalaksanaan pada pasien dengan Risiko Perilaku Kekerasan

b. Mahasiswa mampu melakukan pengkajian pada pasien dengan RisikoPerilaku Kekerasan

c. Mahasiswa mampu menegakkan diagnosa atau masalah keperawatan pada Ny.H dengan Risiko Perilaku Kekerasan.

d. Mahasiswa mampu menetapkan intervensi keperawatan secara menyeluruh pada Ny.Hdengan Risiko Perilaku Kekerasan. 
e. Mahasiswa mampu melakukan tindakan keperawatan yang nyata pada Ny.H dengan RisikoPerilaku Kekerasan.

f. Mahasiswa mampu mengevaluasi sebagai tolak ukur guna menerapkan asuhan keperawatan pada Ny.H dengan Risiko Perilaku Kekerasan.

g. Mahasiswa mampu mendokumentasikan asuhan keperawatan pada Ny.H dengan Risiko Perilaku Kekerasan.

\subsection{Manfaat}

\section{Pasien}

Diharapkan tindakan yang telah di ajakarkan dapat di terapkan secara mandiri untuk mengontrol emosi dan untuk mendukung kelangsungan kesehatan pasien

\section{Keluarga}

Diharapkan keluarga dapat memberikan dukungan moral, emosional dan spiritual serta membantu dalam menerapkan asuhan keperawatan jiwa kepada pasien dengan masalah risiko perilaku kekerasan

\section{Institusi Pendidikan}

Bagi institusi pendidikan diharapkan untuk menjadi acuan dalam dalam melakukan kegiatan kemahasiswaan dalam bidang keperawatan jiwa. 


\section{BAB 2}

\section{TINJAUAN TEORITIS}

\subsection{Resiko Perilaku Kekerasan}

\subsubsection{Pengertian}

Risiko perilaku kekerasan merupakan salah satu respon marah diekspresikan dengan melakukan ancaman, mencederai diri sendiri maupun orang lain dan dapat merusak lingkungan sekitar. Tanda dan gejalarisiko perilaku kekerasan dapat terjadi perubahan pada fungsi kognitif, afektif, fisiologis, perilaku dan sosial. Pada aspek fisik tekanan darah meningkat, denyut nadi dan pernapasan meningkat, mudah tersinggung, marah, amuk serta dapat mencederai diri sendiri maupun orang lain (Pardede \& Hulu, 2020)

Perilaku kekerasan merupakan suatu bentuk perilaku yang bertujuan untuk melukai seseorang secara fisik maupun psikologis.Berdasarkan definisi tersebut maka perilaku kekerasan dapat dilakukan secara verbal, diarahkan pada diri sendiri, orang lain, dan lingkungan. Perilaku kekerasan pada orang lain adalah tindakan agresif yang ditujukan untuk melukai atau membunuh orang lain. Perilaku kekerasan pada lingkungan dapat berupa perilaku merusak lingkungan, melempar kaca, genting dan semua yang ada di lingkungan. (Putri \& Fitrianti, 2018)

Perilaku kekerasan adalah merupakan bentuk kekerasan dan pemaksaan secara fisik maupun verbal ditunjukkan kepada diri sendiri maupun orang lain. Perilaku kekerasan adalah salah satu bentuk perilaku yang bertujuan untuk melukai seseorang secara fisik maupun psikologi. Perilaku agresif dan perilaku kekerasan sering dipandang sebagai rentang dimana agresif verbal di suatu sisi dan perilaku kekerasan (violence) di sisi yanglain. Suatu keadaan yang menimbulkan emosi, perasaan frustasi, benci atau marah.Hal ini akan mempengaruhi perilaku seseorang. Berdasarkan keadaan emosi secara mendalam tersebut terkadang perilaku menjadi 
agresif atau melukai karena penggunaan koping yang kurang bagus. (Kandar \& Iswanti, 2019). Tanda dan gejala risiko perilaku kekerasan dapat terjadi perubahan pada fungsi kognitif, afektif, fisiologis, perilaku dan sosial. Pada aspek fisik tekanan darah

\subsubsection{Tanda dan Gejala}

meningkat, denyut nadi dan pernapasan meningkat, mudah tersinggung, marah, amuk serta dapat mencederai diri sendiri maupun orang lain. (Pardede, Siregar \& Hulu, 2020)

Tanda dan gejala perilaku kekerasan berdasarkan standar asuhan keperawatan jiwa dengan masalah resiko perilaku kekerasan (Pardede, 2020)

1. Emosi: tidak adekuat, tidak aman, rasa terganggu, marah (dendam) jengkel

2. Intelektual: mendominasi, bawel, sarkasme, berdebat, meremehkan

3. Fisik: muka merah, Pandangan tajam, napas pendek, keringat, sakit fisik, penyalahgunaan zat, tekanan darah meningkat

4. Spiritual: kemahakuasaan, kebijakan/kebenaran diri, keraguan, tidak bermoral, kebejatan, kreativitas terlambat

5. Sosial: menarik diri, pengasingan, penolakan, kekerasan, ejekan, humor

Tanda dan gejala perilaku kekerasan berdasarkan :

1. Subjektif: mengungkapkan perasaan kesal atau marah, keinginan untuk melukai diri sendiri, orang lain dan lingkungan, klien suka membentak dan menyerang orang lain

2. Objektif : mata melotot atau pandangan tajam, tangan mengepal dan rahang mengatup, wajah memerah, postur tubuh kaku, bicara kasar, ketus, amuk/agresif, menyerang orang lain dan melukai diri sendiri/orang lain 


\subsubsection{Rentang Respon Marah}

Rentang respon kemarahan dari perilaku kekerasan dapat di gambarkan sebagai berikut, assertif, frustasi, pasif, agresif, dan mengamuk. ( Putri, N \& Fitrianti, 2018)

\section{Adaptif}

Maladaptif

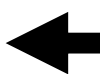
Asertif
Frustasi
Pasif
Agresif
Amuk

Gambar 2.1 Rentang Respon Marah (Habbi et al., 2017)

\section{Keterangan :}

1. Assertif adalah mengungkapkan marah tanpa menyakiti, melukai perasaan orang lain, atau tanpa merendahkan harga diri orang lain.

2. Frustasi adalah respon yang timbul akibat gagal mencapai tujuan atau keinginan. Frustasi dapat dialami sebagai suatu ancaman dan kecemasan. Akibat dari ancaman tersebut dapat menimbulkan kemarahan.

3. Pasif adalah respon dimana individu tidak mampu mengungkapkan perasaan yang dialami.

4. Agresif merupakan perilaku yang menyertai marah namun masih dapat dikontrol oleh individu. Orang agresif bisaanya tidak mau mengetahui hak orang lain. Dia berpendapat bahwa setiap orang harus bertarung untuk mendapatkan kepentingan sendiri dan mengharapkan perlakuan yang sama dari orang lain.

5. Amuk adalah rasa marah dan bermusuhan yang kuat disertai kehilangan control diri. Pada keadaan ini individu dapat merusak dirinya sendiri maupun terhadap orang lain. 


\subsubsection{Pohon Masalah}

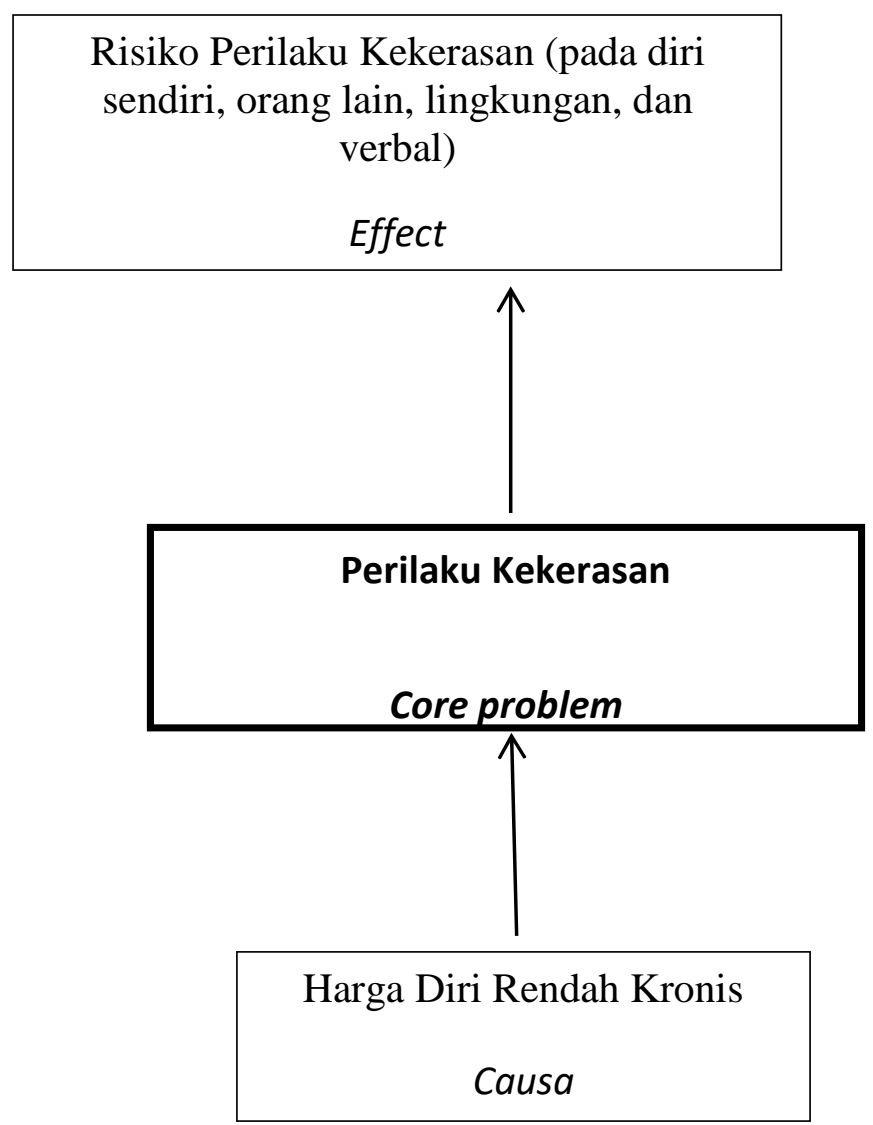

(Nurhalimah, 2016)

\subsubsection{Etiologi}

Menurut Nurhalimah (2016) Proses terjadinya perilaku kekerasan pada pasien akan dijelaskan dengan menggunakan konsep stress adaptasi Stuart yang meliputi faktor predisposisi dan presipitasi

\section{a. Faktor Predisposisi}

1) Faktor Biologis

Hal yang dikaji pada faktor biologis meliputi adanya faktor herediter yaitu adanya anggotakeluarga yang sering memperlihatkan atau melakukan perilaku kekerasan, adanya anggota keluarga yang mengalami gangguan jiwa, adanyan riwayat penyakit atau trauma kepala, dan riwayat penggunaan NAPZA (narkoti, psikotropika dan zat aditif lainnya). 
2) Faktor Psikologis

Pengalaman marah merupakan respon psikologis terhadap stimulus eksternal, internal maupun lingkungan.Perilaku kekerasan terjadi sebagai hasil dari akumulasi frustrasi.Frustrasi terjadi apabila keinginan individu untuk mencapai sesuatu menemui kegagalan atau terhambat.Salah satu kebutuhan manusia adalah "berperilaku", apabila kebutuhan tersebut tidak dapat dipenuhi melalui berperilaku konstruktif, maka yang akan muncul adalah individu tersebut berperilaku destruktif.

3) Faktor Sosiokultural

Teori lingkungan sosial (social environment theory)menyatakan bahwa lingkungan sosial sangat mempengaruhi sikap individu dalam mengekspresikan marah.Norma budaya dapat mendukung individu untuk berespon asertif atau agresif.Perilaku kekerasan dapat dipelajari secara langsung melalui proses sosialisasi (social learning theory).

\section{b. Faktor Prespitasi}

Faktor presipitasi perilaku kekerasan pada setiap individu bersifat unik, berbeda satu orang dengan yang lain.Stresor tersebut dapat merupakan penyebab yang brasal dari dari dalam maupun luar individu. Faktor dari dalam individu meliputi kehilangan relasi atau hubungan dengan orang yang dicintai atau berarti (putus pacar, perceraian, kematian), kehilangan rasa cinta, kekhawatiran terhadap penyakit fisik, dll. Sedangkan faktor luar individu meliputi serangan terhadap fisik, lingkungan yang terlalu ribut, kritikan yang mengarah pada penghinaan, tindakan kekerasan.

\subsubsection{Penatalaksanaan}

Penanganan yang dilakukan untuk mengontrol perilaku kekerasan yaitu dengan cara medis dan non medis. Terapi medis yang dapat di berikan 
seperti obat antipsikotik adalah Chlorpoazine(CPZ), Risperidon(RSP) Haloperidol(HLP), Clozapindan Trifluoerazine (TFP). Psikofarmaka adalah terapi menggunakan obat dengan tujuan untuk mengurangi atau menghilanggan gejala gannguan jiwa. Dengan demiakian kepatutan mium obat 10adalah mengonsumsi obat yang direspkan oleh dokter pada waktu dan dosis yang tepat karena pengobatan hanya akan efektif apabila penderita memenuhi aturan dalam penggunaan obat (Pardede, Keliat \& Yulia, 2015).

Tindakan yang dilakukan perawat dalam mengurangi resiko perilaku kekerasan salah satunya adalah dengan menggunakan strategipelaksanaan (SP). SP merupakan pendekatan yang bersifat membina hubungan saling percaya antaraklien dengan perawat, dan dampak apabila tidakdiberikan SP akan membahayakan diri sendirimaupun lingkungannya. Strategi pelaksanaan (SP) yang dilakukan olehklien dengan perilaku kekerasan adalah diskusimengenai cara mengontrol perilaku kekerasan secara fisik, obat, verbal, dan spiritual.Mengontrol perilaku kekerasan secara fisik dapatdilakukan dengan cara nafas dalm, dan pukulbantal atau kasur. Mengontrol secara verbal yaitudengan cara menolak denganbaik, memintadengan baik,dan mengungkapkan dengan baik.Mengontrol perilaku kekerasan secara spiritualdengan cara shalat dan berdoa. Serta mengontrolperilaku kekerasan dengan minum obat secarateraturdengan prinsip lima benar (benar klien,benar namaobat, benar cara minum obat, benarwaktu minum obat, dan benar dosis obat). ( Sujarwo \& Livana, 2018)

\subsection{Konsep Dasar Keperawatan}

Menurut Yusuf (2015) Proses keperawatan jiwa dimulai dari pengkajian (termasuk analisis data dan pembuatan pohon masalah), perumusan diagnosis, pembuatan kriteria hasil, perencanaan, implementasi, dan evaluasi. 


\subsubsection{Pengkajian}

Pengkajian merupakan tahap awal dan dasar utama dari proses keperawatan dan merupakan suatu proses yang sistematis dalam pengumpulan data dari berbagai sumber untuk mengevaluasi dan mengidentifikasi status kesehatan pasien. Seorang perawat harus berjaga-jaga terhadap adanya peningkatan agitasi pada klien, hierarki perilaku agreisf dan kekerasan. Disamping itu, perawat harus mengkaji pula afek klien yang berhubungan dengan perilaku agresif. ( Muhith, 2015)

Pengkajian dilakukan dengan cara wawancara dan observasi pada pasien dan keluarga. Tanda dan gejala risiko perilaku kekerasan dapat ditemukan dengan wawancara ( Nurhalimah, 2016)

\section{Identitas}

Nama, umur, jenis kelamin, No MR, tanggalmasuk RS, tanggal pengkajian

\section{Alasan masuk}

Biasanya klien masuk dengan alasan sering mengamuk tanpa sebab, memukul, membanting, mengancam, menyerang orang lain, melukai diri sendiri, mengganggu lingkungan, bersifat kasa dan pernah mengalami gangguan jiwa dimasa lalu kambuh karena tidak mau minum obat secara teratur

\section{Faktor predisposisi}

a. Gangguan jiwa dimasa lalu

b. Biasanya klien pernah mengalami gangguan jiwa pada masa lalu dan pernah dirawat atau baru pertama kali mengalami gangguan jiwa

c. Pengobatan sebelumnya

d. Biasanya klien berobat untuk pertama kalinya ke dukun sebagai alternative serta memasung dan bila tidak berhasil baru di bawa kerumah sakit jiwa

e. Trauma 
f. Biasanya klien pernah mengalami atau menyaksikan penganiayaan fisik, seksual, penolakan, dari lingkungan

g. Herediter

h. Biasanya ada anggota keluarga yang mengalami gangguan jiwa, kalau ada hubungan dengan keluarga, gejala, pengobatan dan perawatan.

i. Pengalaman masa lalu yang tidak menyenangkan

j. Biasanya klien pernah mengalami pengalaman masa lalu yang tidak menyenangkan misalnya, perasaan ditolak, dihina, dianiaya, penolakan dari lingkungan

\section{Fisik}

a. Ukur dan observasi itanda-tanda vital seperti tekanan darah akan bertambah naik, nadi cepat, suhu, pernapasan terlihat cepat

b. Ukur tinggi badan dan berat badan

c. Yang kita temukan pada klien dengan prilaku kekerasan pada saat pemeriksaan fisik (mata melotot, pandangan tajam, tangan mengepal, rahang mengatup, wajah memerah)

d. Verbal (mengancam, mengupat kata-kata kotor, berbicara kasar dan ketus)

\section{Psikososial}

1. Genogram

Genogram dibuat 3 generasi keatas yang dapat menggambar kan hubungan klien dengan keluarga. Tiga generasi ini dimaksud jangkauan yang mudah diingat oleh klien maupun keluarga pada saat pengkajian.

2. Konsep diri

Citra tubuh

Biasanya ada anggota tubuh klien yang tidak disukai klien yang mempengaruhi keadaan klien saat berhubungan dengan 
orang lain sehingga klien merasa terhina, diejek dengan kondisinya tersebut.

3. Identitas

Biasanya pada klien dengan prilaku kekerasan tidak puas dengan pekerjaan nya, tidak puas dengan statusnya, baik disekolah, tempat kerja dan dalam lingkungan tempat tinggal

4. Harga diri

Biasanya klien dengan risiko prilaku kekerasan hubungan dengan orang lain akan terlihat baik, harmonis atau terdapat penolakan atau klien merasa tidak berharga, dihina, diejek dalam lingkungan keluarga maupun diluar lingkungan keluarga. Harga diri kerap berkaitan dengan depresi yang ditandai dengan perasaan yang tidak pas, menurunnya kegiatan, dan pesimisme menghadapi masa yang akan datang ( Dirgayunita, 2016)

a. Peran diri

Biasanya klien memiliki masalah dengan peran atau tugas yang di embannya dalam keluarga, kelompok atau masyarakat dan biasanya klien tidak mampu melaksanakan tugas dan peran tersebut dan merasa tidak berguna.

b. Ideal diri

Biasanya klien memilki harapan yang tinggi terhadap tubuh, posisi dan perannya baik dalam keluarga, sekolah, tempat kerja dan masyarakat.

c. Harga diri

Biasanya hubungan klien dengan orang lain tidak baik, penilaian dan penghargaan terhadap diri dan kehidupannya yang selalu mengarah pad apenghinaan dan penolakan. 


\section{Hubungan sosial}

a. Orang yang berarti Tempat mengadu, berbicara

b. Peranserta dalam kegiatan kelompok

Kegiatan yang diikuti klien dalam masyarakat dan apakah klien berperan aktif dalam kelompok tersebut

c. Hambatan dalam berhubungan dengan orang lain/tingkat keterlibatan klien dalam hubungan masyarakat

\section{Spiritual}

a. Nilai dan keyakinan

Biasanya klien mengatakan bahwa dia tidak mengalami gangguan jiwa.

b. Kegiatan ibadah

c. Biasaya dalam selama sakit klienj arang melakukani badah.

\section{Status mental}

a. Penampilan

b. Biasanya penampilan klien kotor.

c. Pembicaraan

d. Biasanya pada klien prilaku kekerasan pada saat dilakukan pengkajian bicara cepat,keras, kasar, nada tinggi dan mudah tersinggung.

e. Aktivitas motorik

f. Biasanya aktivitas motoric klien dengan prilaku kekerasan akan terliha ttegang, gelisah, gerakan otot muka berubah-ubah, gemetar, tangan mengepal, dan rahang dengan kuat.

g. Alam perasaan

Biasanya akan merasa sedih dan menyesali apa yang telah dilakukan

h. Efek 
Biasanya klien mudah tersinggung dan sering marah-marah tanpa sebab

i. Interaksi selama wawancara

Biasanya klien dengan risiko prilaku kekerasan akan terlihat bermusuhan, curiga, tidak kooperatif, tidak mau menatap lawan bicara dan mudah tersinggung.

j. Persepsi

Biasanya klien dengan prilaku kekerasan masih dapat menjawab pertanyaan dengan jelas

k. Isi Pikir

Biasanya klien meyakini diri nya tidak sakit, dan baik-baik saja

1. Tingkat kesadaran

Biasanya klien prilaku kekerasan kadang tampak bingung,

m. Memori

Biasanya klien diwaktu wawancara dapat mengingat kejadian yang terjadi dan mengalami gangguan daya ingat jangka panjang.

n. Kemampuan penilaian

Biasanya klien mengalami kemampuan penilaian ringan dan sedang dan tidak mampu mengambil keputusan

\section{Kebutuhan persiapan pulang}

a. Makan

Biasanya klien tidak mengalami perubahan

b. $\mathrm{BAB} / \mathrm{BAK}$

Biasanya klien dengan risiko prilaku kekerasan tidak ada gangguan

c. Mandi

d. Biasanya klien jarang mandi, tidak menyikat gigi, jarang mencuci rambut dan bercukur atau berhias. Badan klien sangat 
bau dan kotor, dan klien hanya melakukan kebersihan diri jika disuruh.

e. Berpakaian

Biasanya klien jarang mengganti pakaian, dan tidak mau berdandan. Klien tidak mampu mengenakan pakaian dengan sesuai dan klien tidak mengenakan alas kaki

f. Istirahat dan tidur

Biasanya klien tidak melakukan persiapan sebelum tidur, seperti: menyikat gigi, cucui kaki, berdoa. Dan sesudah tidur seperti: merapikan tempat tidur, mandi atau cuci muka dan menyikat gigi. Frekuensi tidur klien berubah-ubah, kadang nyenyak dan kadang gaduh atau tidak tidur.

g. Penggunaan obat

Biasanya klien mengatakan minum obat 3 kali sehari dan klien tidak mengetahui fungsi obat dan akibat jika putus minum obat.

h. Pemeliharaan kesehatan

Biasanya klien tidak memperhatikan kesehatan nya, dan tidak peduli tentang bagai mana cara yang baik untuk merawat dirinya.

i. Aktifitas didalam rumah

Biasanya klien mampu merencanakan, mengolah, dan menyajikan makanan, merapikan rumah, mencuci pakaian sendiri dan mengatu rbiaya sehari-hari.

\section{Masalah psikologis dan lingkungan}

Biasanya klien merasa ditolak dan mengalami masalah interaksi dengan lingkungan

\subsubsection{Diagnosa Keperawatan Jiwa}

Diagnosis keperawatan ialah identifikasi atau penilaian terhadap pola respons klien baik actual maupun potensial dan merupakan dasar pemilihan intervensi dalam mencapai tujuan yang telah di tetapkan oleh perawat yang bertanggung jawab. 
1. Data subjektif : klien mengatakan jengkel dengan orang lain, mengupkankan rasa permusuhan yang mengancam, klien merasa tidak nyaman, klien merasa tidak berdaya, ingin berkelahi, dendam.

2. Data objektif : suara keras, tangan mengepal, wajah memerah dan tegang, pandnagan tajam, mengatupkan rahang dengan kuat, mengepalkan tangan, bicara kasar, suara nada tinggi. ( Nurhalimah, 2016)

\subsubsection{Intervensi Keperawatan}

Tindakan keperawatan untuk mengatasi risiko perilaku kekerasan, dilakukan terhadap pasien dan keluarga. Saat melakukan pelayanan di Puskesmas dan kunjungan rumah, perawat menemui keluarga terlebih dahulu sebelum menemui pasien. Bersama keluarga, perawat mengidentifikasi masalah yang dialami pasien dan keluarga. Setelah itu, perawat menemui pasien untuk melakukan pengkajian, mengevaluasi dan melatih satu cara lagi untuk mengatasi masalah yang dialami pasien. (Nurhalimah, 2016)

Rencana Keperawatan pada diagnosa pasien dengan risiko perilaku kekerasan seperti pada tabel dibawah ini

\begin{tabular}{|c|c|c|c|c|}
\hline \multirow{3}{*}{$\begin{array}{c}\text { DX } \\
\text { Perilaku } \\
\text { kekerasan }\end{array}$} & \multicolumn{4}{|c|}{ Intervensi } \\
\hline & Tuj & & Kriteria evaluasi & Intervensi \\
\hline & $\mathrm{Pa}$ & $\begin{array}{l}\text { Men mampu } \\
\text { i penyebab dan } \\
\text { tanda perilaku } \\
\text { kekerasan } \\
\text { Menyebutkan } \\
\text { jenis perilaku } \\
\text { kekerasan yang } \\
\text { pernah } \\
\text { dilakukan }\end{array}$ & $\begin{array}{l}\text { Setelah pertemuan } \\
\text { pasien mampu : } \\
\text { - Menyebutk } \\
\text { an } \\
\text { penyebab, } \\
\text { tanda, } \\
\text { gejala dan } \\
\text { akibat } \\
\text { perilaku } \\
\text { kekerasan }\end{array}$ & $\begin{array}{l}\text { - Identifikasi } \\
\text { penyebab tanda } \\
\text { dan gejala serta } \\
\text { akibat perilaku } \\
\text { kekerasan } \\
\text { - Latih secara fisik 1 } \\
\text { : tarik nafas dalam } \\
\text { Masukkan dalam } \\
\text { jadwal harian }\end{array}$ \\
\hline
\end{tabular}




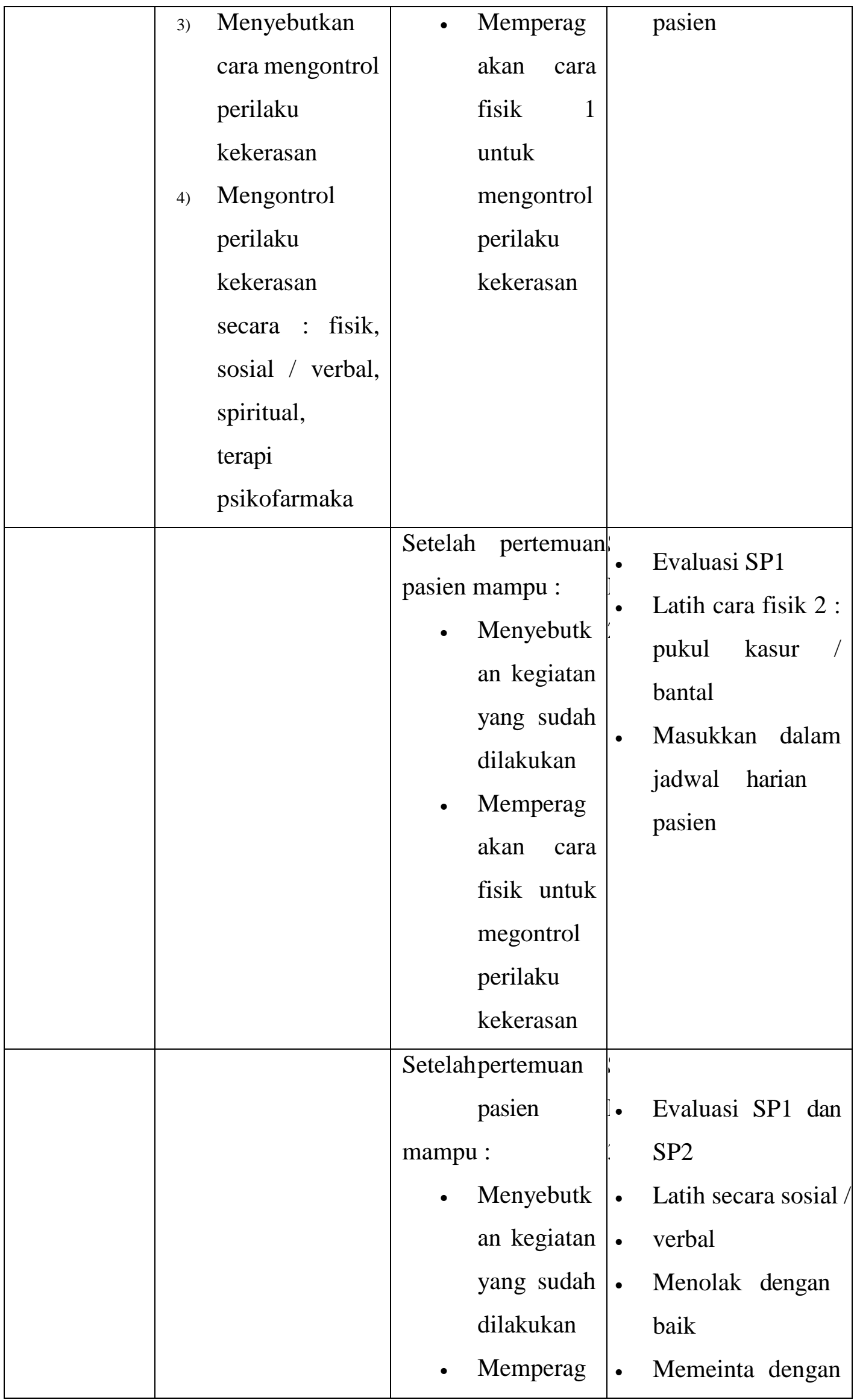




\begin{tabular}{|c|c|c|c|}
\hline & & $\begin{array}{l}\text { akan seara } \\
\text { fisik untuk } \\
\text { mengontrol } \\
\text { perilaku } \\
\text { kekerasan }\end{array}$ & $\begin{array}{ll} & \text { bik } \\
\text { - } & \text { Mengungkapka } \\
\text { n dengan baik } \\
\text { - } & \text { Masukkan dalam } \\
\text { jadwal kegiatan } \\
\text { pasien }\end{array}$ \\
\hline & & $\begin{array}{c}\text { Setelah pertemuan } \\
\text { pasien } \\
\text { mampu: } \\
\text { - Menyebutka } \\
\mathrm{n} \\
\text { kegiatan } \\
\text { yang sudah } \\
\text { dilakukan }\end{array}$ & $\begin{array}{l}\text { Evaluasi SP 1, } 2 \\
\text { dan } 3 \\
\text { Latih secara } \\
\text { spiritual berdo'a }\end{array}$ \\
\hline
\end{tabular}

Fase-Fase dan Aktifitas Kunjungan Rumah

\begin{tabular}{|l|l|}
\hline Fase & Aktifitas \\
\hline 1. Fase Insiasi & $\begin{array}{l}\text { Klarifikasi sumber rujukan untuk kunjungan } \\
\text { rumah, } \\
\text { Klarifikasi tujuan kunjungan ke rumah } \\
\text { Desain kunjungan ke rumah }\end{array}$ \\
\hline 1. Fase Pra Kunjungan & $\begin{array}{l}\text { Lakukan kontak dengan keluarga, } \\
\text { Satukan persepsi tentang tujuan kunjungan dengan } \\
\text { keluarga, } \\
\text { Apa keinginan keluarga dari kunjungan rumah }\end{array}$ \\
\hline 2. Fase di dalam rumah & $\begin{array}{l}\text { Memperkenalkan diri, identitas diri dan } \\
\text { professional. } \\
\text { Interaksi sosial } \\
\text { Tetapkan hubungan P \& K, } \\
\text { Implementasikan proses keperawatan }\end{array}$ \\
\hline
\end{tabular}




\begin{tabular}{|l|l|}
\hline 4.Fase terminasi & $\begin{array}{l}\text { Telaah (evaluasi) kunjungan dengan keluarga } \\
\text { Rencanakan untuk kunjungan berikutnya }\end{array}$ \\
\hline 5.Fase paska kunjungan & $\begin{array}{l}\text { Catat hasil Kunjungan Rencanakan } \\
\text { kunjunganberikutnya }\end{array}$ \\
\hline
\end{tabular}

\subsubsection{Implementasi Keperawatan Jiwa}

Implementasi keperawatan disesuaikan dengan rencana tindakan keperawatan dengan memperhatikan dan mengutamakan masalah utama yang aktual dan mengancam integritas klien beserta lingkungannya. Sebelum melaksanakan tindakan keperawatan yang sudah direncanakan, perawat perlu menvalidasi apakah rencana tindakan keperawatan masih dibutuhkan dan sesuai dengan kondisi klien pada saat ini. Hubungan saling percaya antara perawat dengan klien merupakan dasar utama dalam pelaksanaan tindakan keperawatan.

Tindakan keperawatan dengan pendekatan strategi pelaksanaan (SP) perilaku kekerasan terdiri dari : SP 1 (pasien) : maembantu klien mengontrol perilaku kekerasan dengan memukul bantal atau kasur. SP 2 (pasien) : (pasien) : membantu klien dalam meminum obat seacara teratur. SP 3 (pasien) : Membantu klien mengontrol perilaku kekerasan seacara verbal seperti menolak dengan baik atau meminta dengan. SP 4 (pasien) : baik membantu klien mengontrol perilaku kekerasan secara spiritual dengan cara sholat atau berdoa

\subsubsection{Evaluasi Keperawatan Jiwa}

Evaluasi kemampuan pasien mengatasi risiko perilaku kekerasan berhasil apabila pasien dapat:

1) Menyebutkan penyebab, tanda dan gejala perilaku kekerasan, perilaku kekerasan yangbiasadilakukan, dan akibat dari perilaku kekerasan.

2) Mengontrol perilaku kekerasan secara teratur sesuai jadwal:

a. secara fisik: tarik nafas dalam dan pukul bantal/kasur

b. secara sosial/verbal: meminta, menolak, dan mengungkapkan perasaan dengan cara baik 

c. secara spiritual
d. terapi psikofarmaka

3) Mengidentifikasi manfaat latihan yang dilakukan dalam mencegah perilaku kekerasan (Nurhalimah, 2016)

Evaluasi merupakan proses berkelanjutan untuk menilai efek dari tindakan keperawatan pada klien. Evaluasi dilakukan terus menerus pada respons keluarga terhadap tindakan keperawatan yang telah dilaksanakan. Evaluasi proses atau pormatif dilakukan setiap selesai melakukan tindakan.Evaluasi dapat dilakukan dengan menggunakan SOAP sebagai pola pikirnya.

$\mathrm{S}$ : Respon subjektif keluarga terhadap intervensi keperawatan yang telah dilaksanakan.

$\mathrm{O}$ : Respon objektif keluarga terhadap tindakan keperawatan yang telah di laksanakan.

A : Analisa ulang data subjektif dan objektif untuk menyimpukan pakah masalah masih tetap atau muncul masalah baru atau ada data yang kontradikdif dengan masalah yang ada.

$\mathrm{P}$ : Perencanaan atau tindak lanjut berdasar hasil analisa pada respon keluarga. 


\section{BAB 3}

\section{TINJAUAN KASUS}

\subsection{Identitas Klien}

$\begin{array}{lll}\text { Inisial } & : & \text { Ny.H } \\ \text { Jenis kelamin } & : & \text { Perempuan } \\ \text { Umur } & : & 34 \text { Tahun } \\ \text { Agama } & : & \text { Islam } \\ \text { Status } & : & \text { Menikah (Single Parent) } \\ \text { Tanggal pengkajian } & : & 15 \text { Februari 2021 } \\ \text { Informent } & : & \text { Status klien dan komunikasi dengan klien. }\end{array}$

\subsection{Alasan Masuk Rumah Sakit}

Alasan klien pernah masuk rumah sakit jiwa adalah karena keinginannya sendiri untuk menenangkan diri dan klien sering marah-marah, melempar barang yang ada dirumahnya, klien mengatakan pernah memukul orang lain termasuk anaknya.

\subsection{Faktor Predisposisi}

Klien sebelumnya pernah mengalami gangguan jiwa \pm 7 bulan yang lalu tepatnya pada tahun2020 dan pulang kerumah dalam keadaan tenang. Dirumah klien tidak rutin minum obat, tidak mau kontrol ke RSJ sehingga timbul gejala-gejala seperti diatas kemudian klien mulai kambuh lagi pada saat melihat orang berpasangan lewat di hadapan rumahnya dan jika anaknya membawa teman laki-laki ke rumah, klien marah dan tidak segan untuk memukul. Keluarga klien tidak ada yang pernah mengalami gangguan jiwa.

Masalah Keperawatan:Resiko Perilaku kekerasan

Regiment individu Terapeutik inefektif

\subsection{Fisik}

Klien tidak memiliki keluhan fisik, saat dilakukan pemeriksaan tanda-tanda vital, didapatkan hasil TD : 120/80 mmHg ; N : 80x/i ; S : 36,5 $5^{\circ} \mathrm{C}$; P : 20x/i. Klien memiliki tinggi badan $155 \mathrm{~cm}$ dan berat badan $45 \mathrm{Kg}$. 


\subsection{Psikososial}

\subsubsection{Genogram}

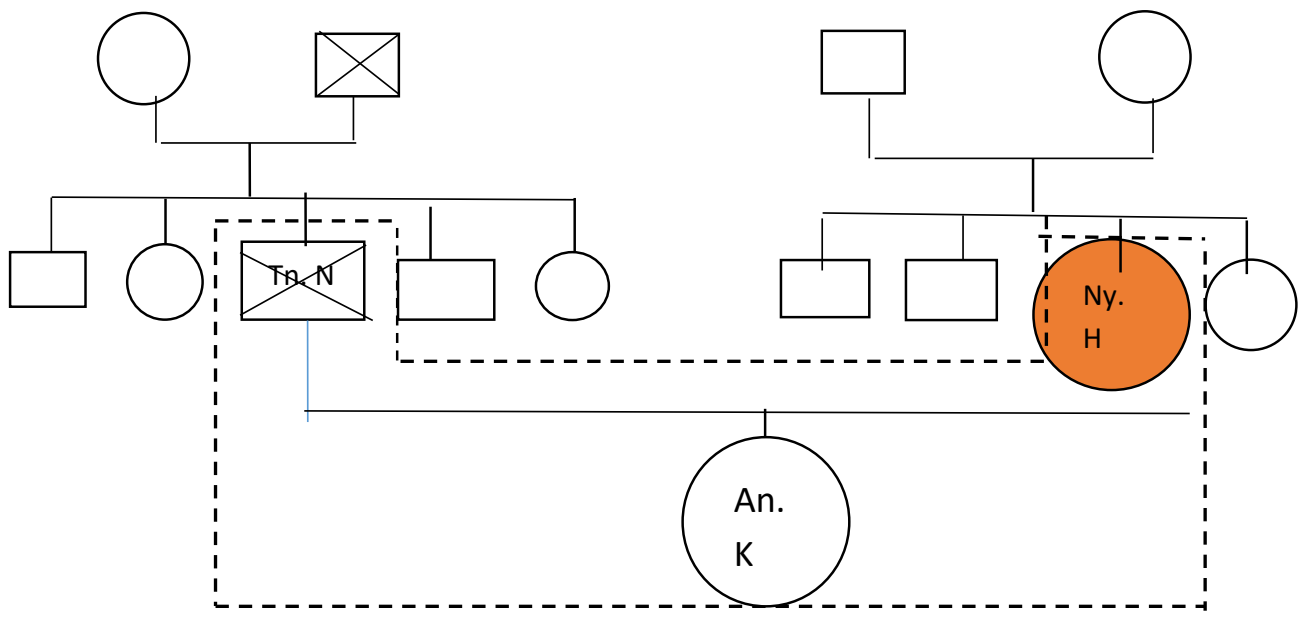

Penjelasan :

Klien menikah dengan Tn.N namun Tn.N sudah meninggal dan saat ini Ny.H tinggal bersama anaknya An.K

Keterangan :

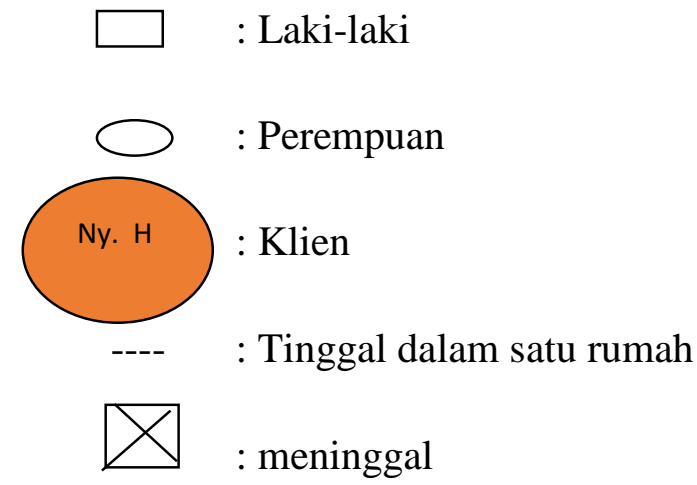

\subsubsection{Konsep diri}
a. Gambaran diri : Tidak ada kecacatan
b. Identitas : Klien anak ke 3 dari 4 bersaudara, klien hanya lulusan SMP yang saat ini hanya berjualan di depan rumah
c. Peran $\quad$ : Klien berperan sebagai istri dan single parent, klien tinggal Bersama anak satu-satunya
d. Ideal diri $\quad$ : Klien merasa malu karena tidak ada suaminya
e. Harga diri $\quad$ : Klien merasa apakah dirinya tidak cantik lagi karena tidak ada laki-laki yang melamarnya lagi dan merasa kesepian semenjak ditinggal suami 
Masalah keperawatan: Gangguan konsep diri : harga diri rendah

\subsubsection{Hubungan sosial}

Klien mengganggap bahwa keluarganya adalah orang yang sangat berartidalam hidupnya, terutama orangtuanya. Klien terkadang mengikuti kegiatan di kelompok/masyarakat. Klien mengatakan mempunyai sedikit hambatan dalam berhubungan dengan orang lain karena klien sulit bergaul

\subsubsection{Spiritual}

a. Nilai dan Keyakinan : Klien beragama islam dan yakin dengan agamanya.

b. Kegiatan Ibadah : Shalat 5 waktu

\subsubsection{Status Mental}

1. Penampilan

Penjelasan $\quad$ : Klien berpenampilan bersih, dan rapi

2. Pembicaraan

Penjelasan

:Klien masih mampu menjawab pertanyaan perawat dengan lambat namun masih dapat dipahami

3. Aktivitas Motorik

Penjelasan : Klien terlihat gelisah

4. Suasana perasaan

Penjelasan : Klien sedih jika melihat pasangan suami-istri lewat depan rumah

Masalah keperawatan : Harga Diri Rendah

5. Afek

Penjelasan : : Afek klien labil, mudah emosi, mudah marah.

Masalah keperawatan : Risiko perilaku kekerasan

6. Interaksi selama wawancara

Penjelasan $\quad$ : Klien kooperatif, ada kontak mata pada lawan bicara mudah tersinggung dalam setiap interaksi.

7. Persepsi

Penjelasan

:tidak mendengar suara-suara aneh

8. Proses Pikir

Penjelasan $\quad$ : Klien mampu menjawab apa yang ditanya dengan baik 
9. Isi pikir

Penjelasan

:Klien dapat mengontrol isi pikirnya,klien tidak mengalami gangguan isi pikir dan tidak ada waham. Klien tidak mengalami fobia, obsesi ataupun depersonalisasi.

10. Tingkat kesadaran

Penjelasan :Klien tidak mengalami gangguan orientasi, klien mengenali waktu, orang dan tempat.

11. Memori

Penjelasan :Klien mampu menceritakan kejadian di masa lalu dan yang baru terjadi.

12. Tingkat konsentrasi berhitung

Penjelasan $\quad$ :Klien mampu berkonsentrasi dalam perhitungan

13. Kemampuan penilaian

Penjelasan

: Klien dapat membedakan hal yang baik dan yang buruk.

14. Daya tilik diri

Penjelasan

: Klien tidak mengingkari penyakit yang diderita, klien mengetahui bahwa dia sering marah

\subsection{Mekanisme Koping}

Klien mengalami mekanisme koping adaptif yaitu klien dapat berbicara baik dengan orang lain dan berkooperatif

\subsection{Masalah Psikososial dan Lingkungan}

Klien mengatakan jarang mengikuti kegiatan di lingkungan rumah

\subsection{Pengetahuan Kurang Tentang Gangguan Jiwa}

Klien tidak mengetahui tentang gangguan jiwa yang di alaminya dan obat yang dikonsumsinya.

\subsection{Analisis Data}

No

Data

1 Subjektif :

Klien mengatakan pernah melempar barangbarang yang ada dirumahnya, pernah memukul orang lain dan marah-marah
Masalah Keperawatan

\section{Resiko Perilaku}

Kekerasan 
Objektif :

Klien tampak memandang orang lain dengan tatapan bermusuhan dan gelisah.

2 Subjektif :

Klien mengatakan pernah tidak ingin keluar rumah hanya ingin berdiam diri di rumah tanpa bertemu dengan banyak orang dan tidak begitu menyukai melihat orang yang dating berpasangan

\section{Objektif :}

Klien tidak aktif dalam acara dilingkungan rumah

3 Subjektif :

Klien merasa tidak dihargai, dan merasa minder dengan orang lain yang memiliki pasangan

\section{Objektif :}

Klien tampak malu

\subsection{Daftar Masalah Keperawatan}
a. Risiko Perilaku Kekerasan
b. Isolasi Sosial
c. Gangguan Konsep Diri : Harga Diri Rendah

\section{Isolasi Sosial}

\section{Gangguan Konsep Diri :}

Harga diri rendah 


\subsection{Pohon Masalah}

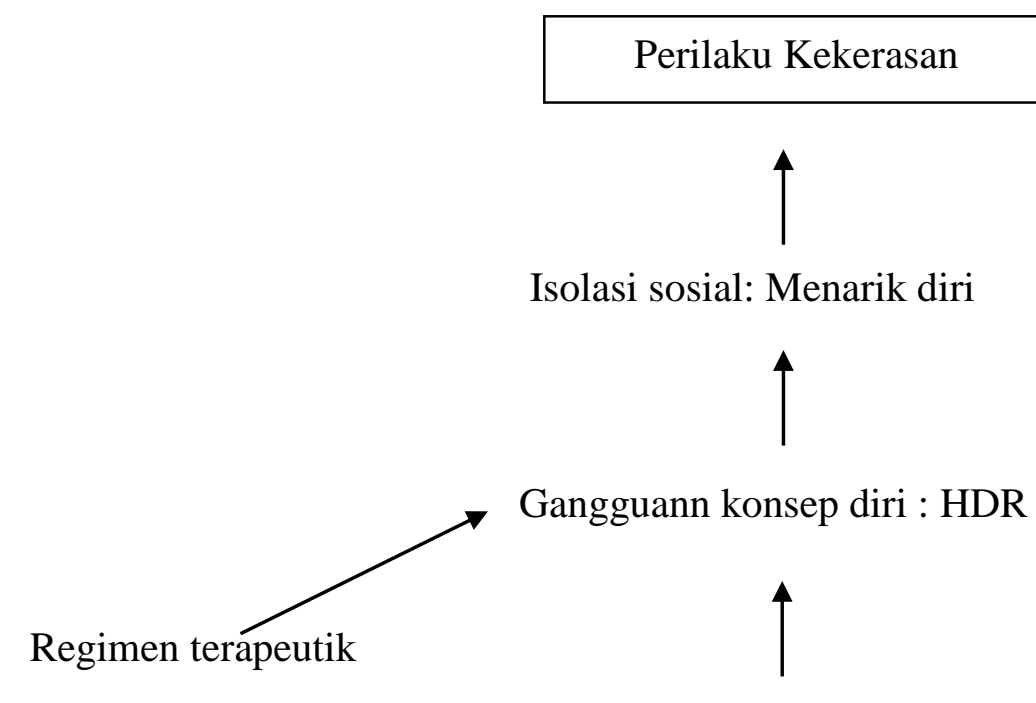

Individu inefektif

Koping individu inefektif

\subsection{Diagnosa Prioritas}

Risiko Perilaku Kekerasan

\subsection{Intervensi Keperawatan}

Diagnosa

Tujuan

Kriteria Hasil

Intervensi

Keperawatan

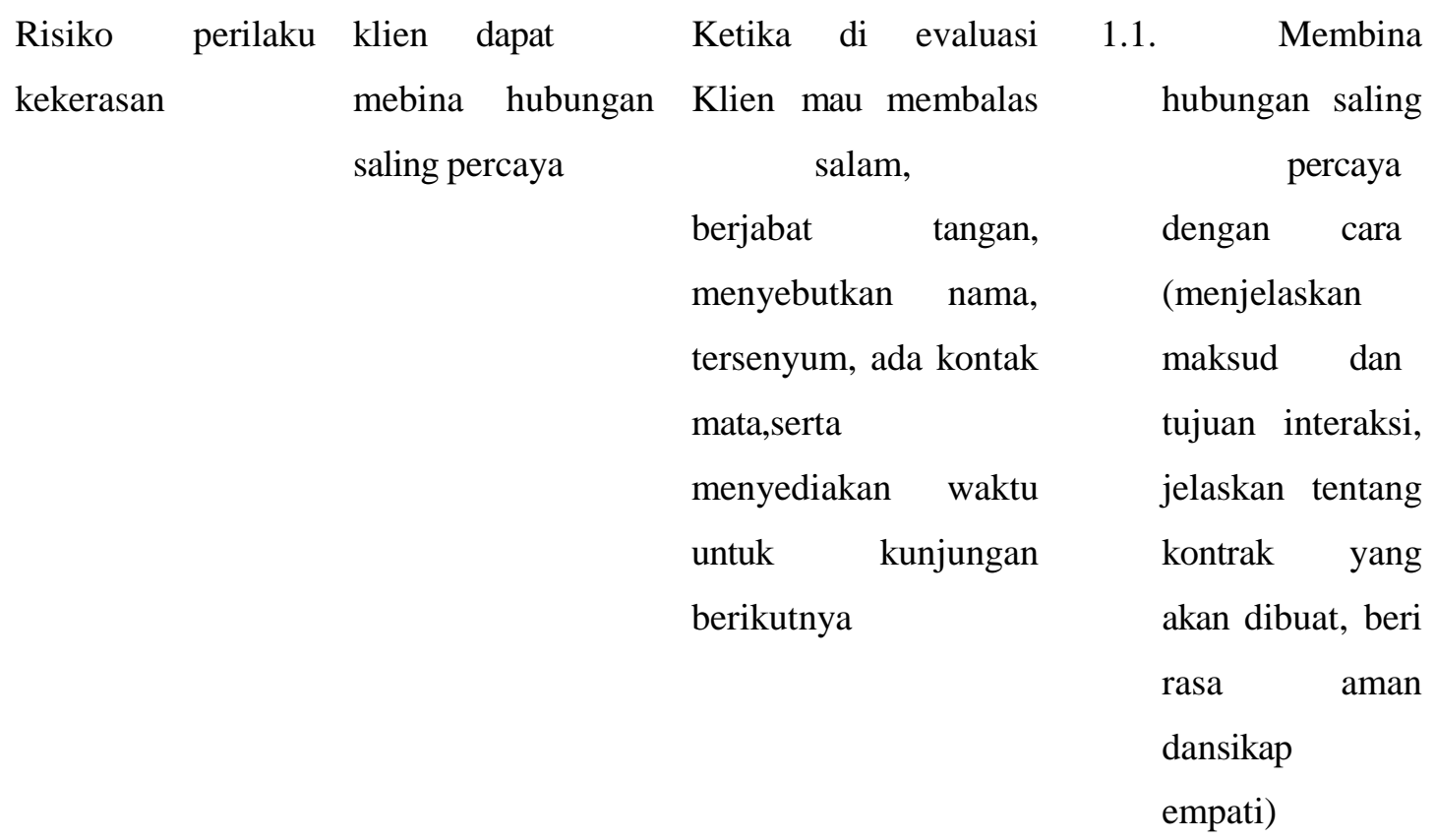

.1.2. Diskusikan 
bersama klien

tentang perilaku

kekerasan

(penyebab, tanda

dan gejala,

perilaku yang

muncul dan

akibat dari

perilaku

tersebut).

\begin{tabular}{|c|c|c|}
\hline Klien dapat & Klien mampu & Sp 1 \\
\hline mengendalikan & menyebutkan dan & Latih \\
\hline perilaku kekerasan & menredemonstrasi & melakukan cara \\
\hline engan & kan cara & mengontrol \\
\hline laksasi & mengontrol perilaku & Kemarahan: \\
\hline $\begin{array}{l} \\
\text { nafas dalam } \\
\text { dan pukul bantal } \\
\text { kasur }\end{array}$ & $\begin{array}{l}\text { kekerasan dengan } \\
\text { cara relaksasi nafas } \\
\text { dalam dan pukul }\end{array}$ & $\begin{array}{l}\text { 1.3. Ajarkan tehnik } \\
\text { relaksasi nafas } \\
\text { dalam }\end{array}$ \\
\hline & bantal & 1.4. Pukul bantal \\
\hline $\begin{array}{l}\text { Klien dapat } \\
\text { mengendalikan }\end{array}$ & $\begin{array}{l}\text { Klien mampu } \\
\text { mengendalikan }\end{array}$ & Sp 2: \\
\hline $\begin{array}{l}\text { perilaku } \\
\text { kekerasan dengan }\end{array}$ & $\begin{array}{l}\text { perilaku kekerasan } \\
\text { dengan minum obat }\end{array}$ & $\begin{array}{lr}\text { Bantu } & \text { klie } \\
\text { mengontrol perilak }\end{array}$ \\
\hline $\begin{array}{l}\text { minum obat } \\
\text { secara } \\
\text { teratur }\end{array}$ & & $\begin{array}{l}\text { kekerasan pasie } \\
\text { dengan minum ob } \\
\text { secara teratur }\end{array}$ \\
\hline $\begin{array}{l}\text { klien paham dan } \\
\text { mampu }\end{array}$ & $\begin{array}{l}\text { Klien paham dan } \\
\text { mampu }\end{array}$ & $\begin{array}{ll}\text { Lakukan SP } & \text { pasien } \\
\text { risiko } & \text { perilaku }\end{array}$ \\
\hline mengendalikan & menyampaikan & kekerasan : Ajarkan \\
\hline perilaku & amarah dengan & kepada klien bicar \\
\hline kekerasan dengan & cara berbicara & yang baik bila sedan \\
\hline cara berbicara & dengan baik & marah. Ada tiga cara: \\
\hline engan baik & & - Meminta \\
\hline
\end{tabular}


- Menolak

denganbaik

- Mengungkapkan

perasaan kesal

Klien paham dan Klien paham dan

Lakukan SP 4

mampu

mampu

pasien risiko

mengendlikan

mengendalikan

perilaku

risiko perilaku risiko perilaku

kekerasan :

kekerasan dengan kekerasan dengan

Diskusikan

cara mempraktikan

caraberibadah

bersama klien

cara spiritual

cara

(beribadah

mengendalikan

risiko perilaku

kekerasan dengan

cara beribadah. 


\subsection{Implementasi dan Evaluasi}

Hari/tgl

Implementasi

Kamis/18-

2-2021

1. Data :
Tanda dan gejala : mudah marah-

marah, mudah tersinggung,tatapan

sinis, ,suka menyendiri, merasa

tidak dihargai

Kemampuan : berjualan didepan

rumah

2. Diagnosa Keperawatan

Risiko Perilaku Kekerasan

Perilaku Kekerasan

3. Tindakan keperawatan:

\section{Sp 1Risiko PerilakuKekerasan:}

- Mengidentifikasi penyebab risiko perilaku kekerasan yaitu jika kemauan klien tidak dituruti

- Mengidentifikasi tanda dan gejala risiko perilaku kekerasan yaitu klien marah, mengamuk tanpa jelas, merusak barang-barang, dan cenderung melukai orang lain

- Menyebutkan cara mengontrol risiko perilaku kekerasan adalah dengan latihan fisik 1 : tarik napas dalam latihan fisik 2 : pukul kasur bantal

\section{Evaluasi}

S : Semangat

O :

- Klien mampu melakukan latihan fisik tarik nafas dalam dengan mandiri

- Klien mampu pukul kasur bantal dengan mandiri

A : Risiko Perilaku kekerasan (+)

P : Latihan fisik :

-Tarik nafas dalam 1x/ hari

-Pukul kasur bantal 1x/ hari 
- Membantu klien latihan tarik napas dalam dan pukul kasur bantal.

\section{RTL:}

Sp2 Risiko Perilaku Kekerasan:

- Mengontrolrisiko perilaku kekerasan dengan minum obat secara teratur

Kamis

$18 / 2 / 2021$
1. Data :

Tanda dan gejala : mudah marahmarah, mudah tersinggung,tatapan sinis, merasa tidak dihargai

Kemampuan : berjualan depan rumah

2. Diagnosa Keperawatan Risiko Perilaku Kekerasan Perilaku Kekerasan

3. Tindakan keperawatan:

\section{$\underline{\text { Sp 2Risiko Perilaku Kekerasan }}$}

1. Mengevaluasi kemampuan klienuntuk tarik nafas dalam dan pukul kasur bantal

2. Memberikan informasi tentang penggunaan obat

\section{RTL:}

Sp 3 Risiko Perilaku Kekerasan
$\mathbf{S}$ : Bahagia dan bersemangat

O :

- Klien mampu melakukan tarik nafas dalam dengan mandiri

- Klin mampu pukul kasur bantal secara mandiri

- Klien mampu ke poli jika merasa kumat dan meminum obat secara teratur dengan bantuan perawat

A : Risiko Perilaku kekerasan $(+)$

\section{P :}

- Latihantarik nafas dalam $1 \mathrm{x} /$ hari 
- Komunikasi secara

verbal:Asertif/bicara baik-baik.
- Latihan pukul kasur bantal $1 \mathrm{x} / \mathrm{hari}$

- berobat

Jumat

1. Data:

S : senang

$19 / 2 / 2021$

Tanda dan gejala : mudah marah-

$\mathbf{O}:$

marah, mudah tersinggung,tatapan sinis, merasa tidak dihargai

Kemampuan : berjualan

2. Diagnosa Keperawatan:

- Klien mampu melakukan komunikasi secara verbal : asertif/bicara baikbaikdengan motivasi

Risiko Perilaku Kekerasan

A : RisikoPerilaku kekerasan $(+)$

Perilaku Kekerasan

3. Tindakan keperawatan:

\section{Sp 3Risiko Perilaku Kekerasan}

- Mengevaluasi kemampuan klien untuk tarik nafas dalam dan pukul kasur bantal

P :

- Latihantarik nafas dalam dan pukul kasur bantal $1 \mathrm{x} /$ hari

- Berobat

- Minum obat

- Klienmelakukan

- Komunikasi secara verbal : komunikasi secara asertif/bicara baik-baik verbal : asertif/bicara baik-baik

\section{RTL:}

Sp 4 Risiko Perilaku Kekerasan:

- Spritual : Beribadah

Jumat

1. Data :

$\mathbf{S}:$ antusias 
Tanda dan gejala : mudah marah-

marah, mudah tersinggung,tatapan

sinis, merasa tidak dihargai

Kemampuan : berjualan

2. Diagnosa Keperawatan:

Risiko Perilaku Kekerasan

\section{Perilaku Kekerasan}

3.Tindakan keperawatan:

\section{Sp 4Risiko Perilaku Kekerasan}

- Mengevaluasi kemampuan klien dalam tarik nafas dalam dan pukul kasur bantal, minum obat secara teratur dan bicara baik-baik.

- Melatih klien untuk melaksanakan kegiatan spiritual yang sudah diatur.

\section{RTL :}

Risiko Perilaku Kekerasan : Follow up dan evaluasi SP 1-4 risiko Perilaku Kekerasan
O :

- Klien mampu melaksanakan kegiatan ibadah dengan baik misalnya Sholat

A : Perilaku kekerasan (+)

P:

- Latihantarik nafas dalam dan pukul kasur bantal $2 \mathrm{x} /$ hari

- Berobat

- Latihan melakukan komunikasi secara verbal : asertif/bicara baik-baik

- Latihan klien untuk melaksanakan kegiatan spiritual yang sudah diatur. 


\section{BAB 4 \\ PEMBAHASAN}

Setelah penulis melaksanakan asuhan keperawatan kepada Ny.H dengan Risiko Perilaku Kekerasan di Desa Juli Seutuy, maka penulis pada BAB ini akan membahasan kesenjangan antara teoritis dengan tinjauan kasus.

Pembahasan dimulai melalui tahapan proses keperawatan yaitu pengkajian, diagnosa keperawatan, perencanaan, pelaksanaan dan evaluasi.

\subsection{Tahap Pengkajian}

Selama pengkajian dilakukan pengumpulan data dari beberapa sumber, yaitu dari pasien dan tetangga sekitar. Maka penulis melakukan pendekatan kepada pasien melalui komunikasi teraupetik yang lebih terbuka membantu klien untuk memecahkan perasaannya dan juga melakukan observasi kepada pasien. Adapun upaya tersebut yaitu:

1. Melakukan pendekatan dan membina hubungan saling percaya diri pada klien agar klien lebih terbuka dan lebih percaya.

2. Mengadakan pengkajian pasien dengan wawancara dan tidak menemukan kesenjangan karena di temukan hal sama seperti diteori bahwasanya perilaku kekerasan merupakan respon maladaptif dari kemarahan, hasil dari kemarahan yang ekstrim ataupun panik. Perilaku kekerasan yang timbul pada klien skizofrenia diawali dengan adanya perasaan tidak berharga, takut,dan ditolak oleh lingkungan sehingga individu akan menyingkir dari hubungan interpersonal dengan orang lain (Pardede, Keliat \& Yulia, 2015).

\subsection{Tahap perencanaan}

Perencanaan dalam proses keperawatan lebih dikenal dengan rencana asuhan keperawatan yang merupakan tahap selanjutnya setelah pangkajian dan penentuan diagnosa keperawatan. Pada tahap perencanaan penulis hanya menyusun rencana tindakan keperawatan sesuai dengan pohon masalah keperawatan yaitu :perilaku kekerasan. Pada tahap ini antara tinjauan teoritis dan tinjaun kasus tidak ada 
kesenjangan sehingga penulis dapat melaksanakan tindakan seoptimal mungkin dan didukung dengan seringnya bimbingan dengan pembimbing

Secara teoritis digunakan cara strategi pertemuan sesuai dengan diagnosa keperawatan yang muncul saat pengkajian. Adapun upaya yang dilakukan penulis yaitu :

1. Risiko Perilaku Kekerasan

a. Mengidentifikasi isi Risiko Perilaku Kekerasan

b. Mengidentifikasi waktu terjadi Risiko Perilaku Kekerasan

c. Mengidentifikasi situasi pencetus Risiko Perilaku Kekerasan

d. Mengidentifikasi respon terhadap Risiko Perilaku Kekerasan

e. Membantu pasien mempraktekan latihan cara mengontrol Risiko Perilaku Kekerasan dengan tarik napas dalam dan pukul kasur bantal

f. Menjelaskan cara mengontrol perilaku kekerasan dengan minum obat

g. Melatih pasien mengontrol Risiko Perilaku Kekerasandengan berbicara baik-baik dengan orang lain dan spritual

h. Mengevaluasi jadwal kegiatan harian pasien

\subsection{Tahap Implementasi}

Pada tahap implementasi, penulis hanya mengatasi 1 masalah keperawatan yakni: diagnosa keperawatan Risiko Perilaku Kekerasandi karenakan masalah utama yang dialami klien. Pada diagnosa keperawatan Risiko Perilaku Kekerasan dilakukan strategi pertemuan yaitu mengidentifikasi Perilaku Kekerasan, mengontrol perilaku kekerasan dengan cara tarik napas dan pukul kasur bantal. Strategi pertemuan yang kedua yaitu anjurkan minum obar secara teratur, strategi pertemuan ketiga yaitu latihan dengan carakomunikasi secara verbal atau bicara baik-baik strategi pertemuan ke empat yaitu Spritual.

\subsection{Tahap evlaluasi}

Pada tinjauan teoritis evaluasi yang diharapkan adalah :

1. Pasien mempercayai perawat sebagai terapis

2. Dapat mengidentifikasi dan mengontrol Risiko Perilaku Kekerasan 
3. Dapat mengendalikan Risiko Perilaku Kekerasan melalui latihan fisik,

4. Dapat mengendalikan Risiko Perilaku Kekerasan dengan cara minum obat secara teratur

5. Dapat mengendalikan Risiko Perilaku Kekerasan dengan berbicara baik-baik

6. Dapat mengendalikan Risiko Perilaku Kekerasan dengan spritual yang terjadwal.

Pada tinjauan kasus evaluasi yang dihasilkan adalah :

1. Klien sudah dapat mengontrol dan mengidentifikasi RisikoPerilaku Kekerasan

2. Klien dapat mengendalikan Risiko Perilaku Kekerasan melalui latihan fisik

3. Klien dapat mengendalikan Risiko Perilaku Kekerasan dengan cara pergi ke poli jiwa untuk mendapatkan minum obat

4. Klien dapat mengendalikan Risiko Perilaku Kekerasan dengan berbicara baikbaik dengan orang lain

5. Klien dapat mengendalikan Risiko Perilaku Kekerasan dengan melakukan spritual terjadwal. 


\section{BAB 5 \\ PENUTUP}

\subsection{Kesimpulan}

Setelah menguraikan tentang proses keperawatan pada Ny.H penulis melanjutkan asuhan keperawatan pada klien dengan risiko perilaku kekerasan di Desa Juli Seutuy. Maka penulis mengambil kesimpulan untuk meningkatkan mutu asuhan keperawatan yang telah ada:

1. Dalam melakukan asuhan keperawatan pada klien dengan kasus perilaku kekerasan dilakukan meliputi aspek psikososial, spiritual dan melibatkan keluarga didalamnya.

2. Dalam melakukan asuhan keperawatan maka antar perawat dan klien harus membina hubungan saling percaya.

3. Bagi mahasiswa/mahasiswi agar lebih memperdalam ilmu pengetahuan khususnya tentang keperawatan jiwa.

4. Bagi klien agar dapat berkomunikasi dan berinteraksi dengan baik serta klien mengikuti pengobatan secara optimal sampai berhasil agar tidak terulang kembali.

5. Peran serta keluarga sangat penting dalam penyembuhan klien karena dengan dukungan keluarga penyembuhan klien dapat tercapai sesuai dengan yang diharapkan.

\subsection{Saran}

1. Diharapkan pada keluarga dan teman agar selalu memberikan dukungan kepada klien karena dukungan dapat memberikan efek yang bagus untuk psikis klien.

2. Bagi mahasiswa /mahasiwi agar lebih memperdalam ilmu pengetahuan khusus tentang keperawatan jiwa. 


\section{DAFTAR PUSTAKA}

Fei, X., Wang, S., Zheng, X., Liu, K., \& Liang, X. (2021). Global research on cognitive behavioural therapy for schizophrenia from 2000 to 2019: a bibliometric analysis via CiteSpace. General Psychiatry, 34(1). doi: 10.1136/gpsych-2020-100327

Dirgayunita, A. (2016). Depresi: Ciri, penyebab dan penangannya. Journal An-Nafs: Kajian Penelitian Psikologi, 1(1), 1-14. https://doi.org/10.33367/psi.v1i1.235

Habbi Yulsar Rahman, F., Widodo, A., \& Kep, A. (2017). Upaya Penurunan Risiko Perilaku Kekerasan Pada Dengan Melatih Asertif Secara Verbal (Doctoral dissertation, Universitas Muhammadiyah Surakarta). http://eprints.ums.ac.id/id/eprint/52404

Kandar, K., \& Iswanti, D. I. (2019). Faktor Predisposisi dan Prestipitasi Pasien Resiko Perilaku Kekerasan. Jurnal Ilmu Keperawatan Jiwa, 2(3), 149-156. http://dx.doi.org/10.32584/iikj.v2i3.226

Muhith, Abdul. (2015). Pendidikan Keperawatan Jiwa. Yogyakarta: Andi

Nurhalimah. (2016). Bahan Ajar Keperawatan Jiwa

Pardede, J. A., \& Hulu, E. P. (2020). Pengaruh Behaviour Therapy Terhadap Risiko Perilaku Kekerasan Pada Pasien Skizofrenia Di Rumah Sakit Jiwa Prof. Dr. Muhammad Ildrem Provsu Medan. Konferensi Nasional (Konas) Keperawatan Kesehatan Jiwa, 4(1), 257-266. https://journalpress.org/proceeding/ipkji/article/view/51/51

Pardede, J. A. (2020). Family Knowledge about Hallucination Related to Drinking Medication Adherence on Schizophrenia Patient. Jurnal Penelitian Perawat Profesional, 2(4), 399-408. https://doi.org/10.37287/jppp.v2i4.183

Pardede, J. A., Simanjuntak, G. V., \& Laia, R. (2020). Gejala Risiko Perilaku Kekerasan Menurun Setelah Diberikan Prgressive Muscle Relaxation Therapy Pada Pasien Skizofrenia. 3 (2). 91-100. http://dx.doi.org/10.32584/jikj.v3i2.534

Pardede, J. A., Keliat, B. A., \& Yulia, I. (2015). Kepatuhan dan Komitmen Klien Skizofrenia Meningkat Setelah Diberikan Acceptance And Commitment Therapy dan Pendidikan Kesehatan Kepatuhan Minum Obat. Jurnal Keperawatan Indonesia, 18(3), 157-166. 10.7454/jki.v18i3.419

Pardede, J.A. (2020). Standar Asuhan Keperawatan Jiwa Dengan Masalah Risiko Perilaku Kekerasan.

Pardede, J. A., Siregar, L. M., \& Hulu, E. P. (2020). Efektivitas Behaviour Therapy Terhadap Risiko Perilaku Kekerasan Pada Pasien Skizofrenia Di Rumah Sakit Jiwa 
Prof. Dr. Muhammad Ildrem Provsu Medan. Jurnal Mutiara Ners,3(1), 8-14. http://114.7.97.221/index.php/NERS/article/view/1005

Putri, V. S., \& Fitrianti, S. (2018). Pengaruh Strategi Pelaksanaan Komunikasi Terapeutik Terhadap Resiko Perilaku Kekerasan Pada Pasien Gangguan Jiwa Di Rumah Sakit Jiwa Provinsi Jambi. Jurnal Akademika Baiturrahim Jambi, 7(2), 138147. http://dx.doi.org/10.36565/jab.v7i2.77

Riskesdas. (2018). Badan Penelitian dan Pengembangan Kesehatan Kementerian RI tahun 2018. https://dinkes.kalbarprov.go.id/wp-content/uploads/2019/03/LaporanRiskesdas-2018 Nasional.pdf

Suerni, T., \& Livana, P. H. (2019). Respons Pasien Perilaku Kekerasan. Jurnal Penelitian Perawat Profesional, 1(1), 41-46. https://doi.org/10.37287/ippp.v1i1.16

Sujarwo, S., \& Livana, P. H. (2019). Studi Fenomenologi: Strategi Pelaksanaan Yang Efektif Untuk Mengontrol Perilaku Kekerasan Menurut Pasien Di Ruang Rawat Inap Laki Laki. Jurnal Keperawatan Jiwa, 6(1), 29-35. https://doi.org/10.26714/ikj.6.1.2018.29-35

Wardani, I. K., \& Prabowo, A. (2020). Efektifitas Terapi Spiritual Wudhu Untuk Mengontrol Emosi Pada Pasien Resiko Perilaku Kekerasan. Tens: Trends of Nursing Science, 1(1), 74-84.https://doi.org/10.36760/tens.v1i1.109

Yusuf, A., Fitryasari PK, R., \& Nihayati, H. E. (2015). Buku ajar keperawatan kesehatan jiwa. 
